\title{
Health care funding model flawed, blue-ribbon CMA panel argues
}

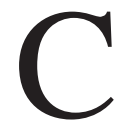

anada's health care system risks "privatization by default" if Canadians continue to refuse to debate alternative models for health care financing and delivery, a Canadian Medical Association advisory panel reported Aug. 22.

Canadians must "look again to the mix of public and private elements" and be open to discussing new ways of funding services in a bid to improve access to care, according to The Report of the Advisory Panel on Resourcing Options for Sustainable Health Care in Canada.

The report also calls for increased provider competition and less micromanagement of the health system by government. It was crafted by a sixmember blue-ribbon panel appointed by the CMA to recommend means to improve governance of the health care system and to generate resources to ensure the system's sustainability.

"Canada faces the pressure of rising demand and limited resources - but so do other developed countries, many of whom are navigating that challenge more successfully while spending less than Canada," the report states. "What distinguishes them from Canada is their more flexible and open approach."

Part of the problem is that many Canadians fear changing the system means "throwing out everything we value" in favour of adopting a "US style" health care model, the report explains.

But demand can be managed without the wholesale privatization of the health system - as it is in many European countries that are outperforming Canada in terms of wait times, out-ofpocket costs and health outcomes - by using innovative payment mechanisms and competition among providers under a publicly determined system of pricing, the report argues.

A discussion of a range of alternative ways of funding the system is imperative, the report states. "At present, apart from Medicare services,

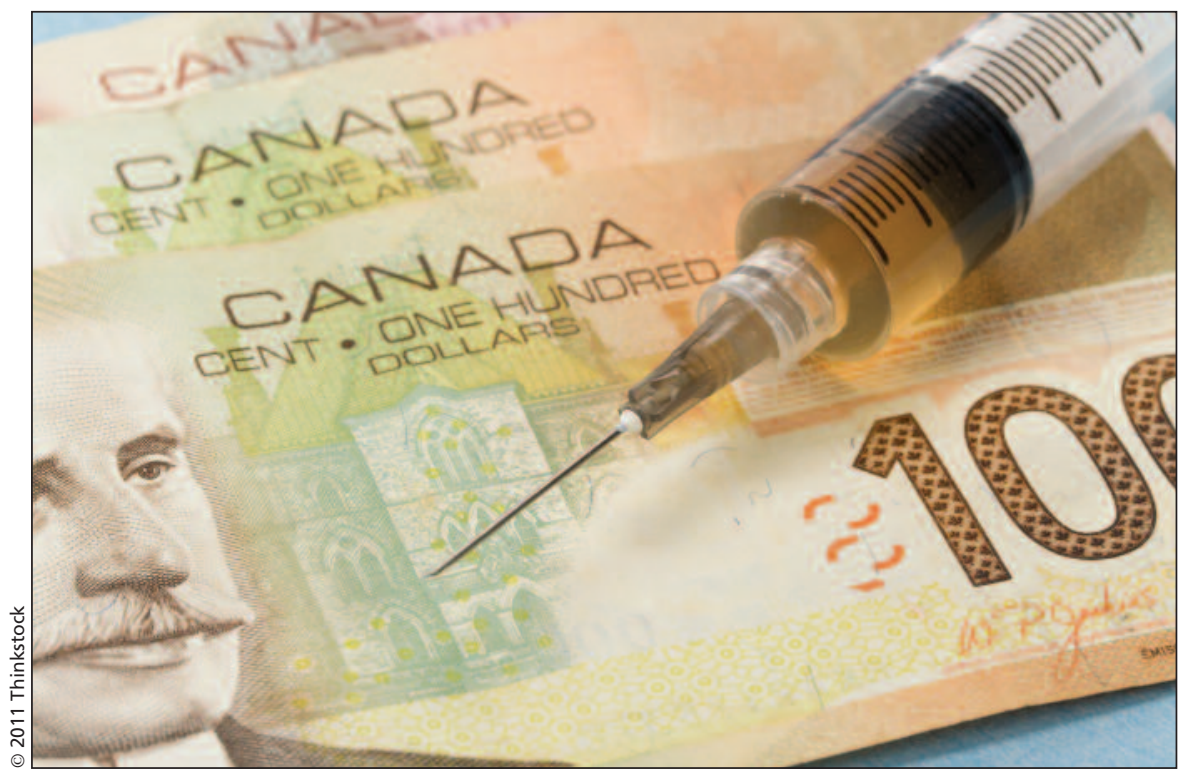

Canada's health care system needs an injection of cash so as to ensure its sustainability and create "the right incentives for better care," according to a Canadian Medical Association advisory panel.

individuals either pay privately for all or a large part of supports across the continuum of care, or forgo them for cost reasons. This is inequitable and also creates the wrong incentives, as individuals naturally turn first to the services for which they do not pay anything, even though other interventions might be faster, better for them and less costly to society as a whole."

"It is time for Canadians to examine the flaws in this model, and to look at other countries that are able to underwrite a wider range of care, generally at lower cost to individuals and to society over all. Such mechanisms as user fees, franchise and various insurance schemes are widely used elsewhere by governments across the political spectrum. Their value is not just in the revenue they provide to help fund the system, but in creating the right incentives for better care."

The funding mechanisms could be used alone or in tandem with raising taxes and cutting spending on other government programs, the report adds.
Provider competition is another crucial element of other national health care systems that Canada should embrace, the advisory panel argues. "This is not privatization, but rather a framework that allows a range of providers - publicsector, private-sector and non-profit to compete in carefully controlled conditions. Services would be funded by government and still subject to government control."

Such a framework for "provider competition" must include "continuing provision of medically necessary services at no cost to patients, competition based on standards of quality as well as price, a level regulatory playing field that applies to public, private and non-profit providers and ensures appropriate minimum standards, licensing and other protections; and transparent criteria for requests for proposals, determination of prices and the awarding of contracts," the report adds.

Governments, meanwhile, should abandon their urge to micromanage the health care system and follow a "loose-tight" approach to governance, 
with "a tight focus on desired outcomes and performance standards but greater flexibility for those within the system to achieve desired outcomes," the report argues.

A "top-down, command-and-control" approach seriously reduces the system's efficiency, argues the panel, which was comprised of Dr. Philippe Couillard (former Quebec health minister), Tony Dagnone (commissioner of Saskatchewan's Patient First Review), Don Drummond (former chief economist for the TorontoDominion Bank), Sister Elizabeth Davis (congregational leader of the Sisters of Mercy of Newfoundland and Labrador), John Horne (adjunct professor of health economics at Royal Roads University in Victoria, British Columbia), and Wendy Thomson (director of the School of Social Work at McGill University in Montréal, Quebec).
"Treating the private sector as something completely separate from the health care system is increasingly risky," the report adds. "Privatization continues to creep in through the back door of our health care system, as governments exclude more services and procedures."

Unregulated, wholesale involvement of the private sector in the financing and delivery of non-medicare services is "inevitable" without changes to our system, the panel warns. "Even with reforms, we must recognize that governments' share of total health care spending will never be $100 \%$."

Other recommendations made by the panel included:

- Adopt activity-based funding for hospitals, which provides payment on the basis of patient-related activities, rather than block funding.

- Update provincial fee schedules so that payment of physicians better reflects the resources used in providing services.

- Develop health quality councils with strong physician representation as a means to set expected outcomes and performance measures.

- Negotiate accountability agreements between physicians, health care organizations and the provinces and territories.

- Work with provincial and territorial associations to contain costs related to pharmaceutical prescriptions.

- Advocate for a rethinking of Canada's national electronic health information strategy and push for greater use of electronic records by physicians.

The panel's report was scheduled for debate at the CMA's 144th annual general meeting being held in St. John's, Newfoundland and Labrador this week. — Lauren Vogel, CMAJ

CMAJ 2011. DOI:10.1503/cmaj.109-3976 